\section{Bovine semen thermoresistance tests and their correlation with pregnancy rates after fixed-time artificial insemination}

[Testes de termoresistência do sêmen bovino e sua correlação com taxas de prenhez após inseminação artificial em tempo fixo]

\author{
R. Talini ${ }^{1}$, L.E. Kozicki ${ }^{2}$, F.R. Gaievski ${ }^{1}$, G. Polo ${ }^{1}$, L.G.F. Lima ${ }^{1}$, \\ J. Santiago ${ }^{3}$, M.S. Segui ${ }^{2}$, R.R. Weiss ${ }^{4}$, T.G.B. Galan ${ }^{5}$ \\ ${ }^{1}$ Programa de pós-graduação - Escola de Ciências da Vida - Pontifícia Universidade Católica \\ do Paraná - Curitiba, PR \\ ${ }^{2}$ Escola de Ciências da Vida - Pontifícia Universidade Católica do Paraná - Curitiba, PR \\ ${ }^{3}$ Médico Veterinário Autônomo - Boa Vista da Aparecida, PR \\ ${ }^{4}$ Engenharia de Bioprocessos e Biotecnologia - Universidade Federal do Paraná - Curitiba, PR \\ ${ }^{5}$ Programa de pós-graduação - Engenharia de Bioprocessos e Biotecnologia - Universidade \\ Federal do Paraná - Curitiba, PR
}

https://orcid.org/0000-0002-4771-1243 L.G.F. Lima

https://orcid.org/0000-0003-2186-9461 R.R. Weiss

https://orcid.org/0000-0002-7218-1184 T.G.B. Galan

https://orcid.org/0000-0002-4821-3422

\begin{abstract}
The objective of the study was to determine whether or not there is a correlation between thermoresistance tests (TT) after semen thawing and pregnancy rate (PR) after fixed-time artificial insemination (FTAI). Four different TT were performed on ten samples used for AI; a rapid test (RTT) $\left(30 \mathrm{~min} / 46^{\circ} \mathrm{C}\right.$ ) and three slow tests (STT): STT1 $\left(60 \mathrm{~min} / 38^{\circ} \mathrm{C}\right)$, STT2 $\left(180 \mathrm{~min} / 38^{\circ} \mathrm{C}\right)$, and STT3 $\left(300 \mathrm{~min} / 38^{\circ} \mathrm{C}\right)$. Two hundred and fifteen multiparous crossbred cows were submitted to FTAI under the following protocol: on day zero (d0) the animals received a $\mathrm{P} 4$ device $+\mathrm{EB}$; on $\mathrm{d} 7 \mathrm{PGF}_{2 \alpha}$; on $\mathrm{d} 8 \mathrm{P} 4$ was removed and $\mathrm{eCG}+\mathrm{EC}$ were administered; IATF was performed on $\mathrm{d} 10$. Three gestational diagnoses (G D) were performed on d40, d70 and d120. The mean sperm motility $(\%)$ in RTT and STTs were $19.84 \pm 6.13,28.55 \pm 10.48,17.62 \pm 5.87$ and $8.63 \pm 3.46$, respectively, and TP in the three DG $61.86 \%, 57.67 \%$, and $55.81 \%$, respectively. Through Person test a significant negative correlation $(\mathrm{P}<0.05)$ was found between STT2 and PR at 60 days $(\mathrm{r}=-0.644)$ and between STT3 and all TPs $(\mathrm{r}=-0.774,-0.752,0.748)$. It was concluded that TT parameters are not able to determine correlation between semen quality and TP.
\end{abstract}

Keywords: sperm motility, casa, pregnancy rate, beef cows, semen thermoresistance test

\title{
RESUMO
}

O objetivo do presente estudo foi determinar se há ou não correlação entre testes de termorresistência (TT) após descongelamento do sêmen e taxa de prenhez (TP) após inseminação artificial em tempo fixo (IATF). Quatro diferentes TT foram realizados nas 10 amostras utilizadas para a IA; um teste rápido (RTT) $\left(30 \mathrm{~min} / 46^{\circ} \mathrm{C}\right)$ e três testes lentos $(\mathrm{STT})$ : STT1 $\left(60 \mathrm{~min} / 38^{\circ} \mathrm{C}\right)$, STT2 $\left(180 \mathrm{~min} / 38^{\circ} \mathrm{C}\right)$ e STT3 $\left(300 \mathrm{~min} / 38^{\circ} \mathrm{C}\right)$. Duzentas e quinze vacas cruzadas multíparas foram submetidas à IATF sob o seguinte protocolo: no dia zero (d0), os animais receberam um dispositivo de P4+EB; em d7, PGF2 $\alpha$; em d8, retirou-se P4 e eCG+EC administrados; no d10, foi realizada IATF. Três diagnósticos gestacionais (DG) foram feitos, em d40, d70 e d120. As médias de motilidade espermática (\%) em RTT e STTs foram 19,84 $\pm 6,13,28,55 \pm 10,48,17,62 \pm 5,87$ e $8,63 \pm 3,46$, respectivamente, e TP nos três DG 61,86\%, 57,67\% e 55,81\%, respectivamente. Por meio do teste de Person, uma correlação negativa significativa $(P<0,05)$ foi encontrada entre os resultados de STT2 e PR aos 60 dias $(r=-0,644)$ e entre STT3 e todas TPs $(r=-0,774,-0,752$ e -0,748). Concluiu-se que parâmetros de TT não são capazes de determinar correlação entre qualidade do sêmen e TP.

Palavras-chave: motilidade espermática, casa, taxa de prenhez, vacas de corte, teste de termorresistência do sêmen

Recebido em 24 de agosto de 2018

Aceito em 25 de janeiro de 2019

E-mail: rafatalini@gmail.com 


\section{INTRODUCTION}

Animal reproduction is one of the factors that guarantees profitability and continuity of the livestock business. Artificial insemination (AI) is a low-cost and an uncomplicated biotechnological procedure used to genetically improve herds to increase reproduction rates (Emerick et al., 2011). Fixed-time artificial insemination (FTAI) is the result of conventional AI evolution because it induces estrus and ovulation in a synchronized manner (a limiting factor to the success of AI), based on hormonal regulation in animals (Sá Filho et al., 2010). The demand for quality and cryopreserved bovine semen has been increasing since the emergence of AI and FTAI (Emerick et al., 2011). Qualitative semen analysis, which includes parameters such as motility, vigor, and sperm morphology is performed in semen collection and freezing centers and is considered the most important test to evaluate the fertility of breeders (Brito, 2016). Although qualitative semen analysis is easy to perform, it is often neglected. In addition, when it is performed, the result does not present any pattern or standardization (Brito, 2016).

Therefore, a computerized method for semen analysis was developed (Computer Assisted Sperm Analysis - CASA), to provide standardization, quality, and accuracy. This method requires a microscope, a digital camera or a similar device, and a computer with a specialized software. This method offers objectivity in the analysis, except the subjective factor, which is liable to imperfections (training, experience, and variations). The thermoresistance tests (TTs) of fresh semen or after thawing are performed to evaluate the integrity of sperm cells during AI. The test was developed by Dimitropoulos (1967) and the procedure involves incubating thawed semen samples at $38^{\circ} \mathrm{C}$ for $5 \mathrm{~h}$ (slow test) or at $46^{\circ} \mathrm{C}$ for $30 \mathrm{~min}$ (rapid test). After any of the tests, thawed semen must have at least $15 \%$ motility to be considered of good quality and fresh semen must have at least $70 \%$ motility to be considered of good quality (Manual..., 1998).

Semen motility is the parameter mostly used to determine semen quality and viability after thawing (Rodríguez-Martínez, 2003). Several publications have associated the motility of semen in vitro with field fertility, but there are divergences in the results. Dimitropoulos (1967), Amann (1989) and Farrell et al. (1998) found a positive correlation between motility and field fertility; whereas Arruda et al. (1992)., Zhang et al. (1999), Graham and Mocé (2005), Vianna et al. (2009), Emerick et al. (2011), Nagy et al. (2015) and Sellem et al. (2015) found no correlation between motility and field fertility.

This study hypothesized that by altering the protocols of the standard TTs with semen incubation times not yet described in the literature, it is possible to establish a positive correlation between sperm motility and pregnancy rate (PR) of animals subjected to FTAI. The aim of this study was to find the correlation between the sperm motility of postthawed bovine semen and pregnancy rate, after a fixed-time artificial insemination using rapid thermoresistance test (RTT, 30min $/ 46^{\circ} \mathrm{C}$ ) and slow thermoresistance tests $\left(\mathrm{STT} 1,60 \mathrm{~min} / 38^{\circ} \mathrm{C}\right.$; $\mathrm{STT} 2,180 \mathrm{~min} / 38^{\circ} \mathrm{C}$; and STT3, $300 \mathrm{~min} / 38^{\circ} \mathrm{C}$ ).

\section{MATERIAL AND METHODS}

The study was carried out during the breeding season of 2016/2017 and involved 215 crossbred suckling bovine females (Nelore $\mathrm{X}$ Aberdeen Angus) obtained from a breeding farm situated at latitude $24^{\circ} 57^{\prime} 21^{\prime \prime}$ South and longitude 53 $27^{\circ} 19^{\prime \prime}$ West. The mean age of the cows was 40 months (30-55), mean weight was $447.5 \mathrm{~kg}(313-590)$, body condition score (BCS) was 3.75 (3.0-4.5) (1= thin, 5= fat (Houghton et al., 1990)), and days open was 55 days (50-65). The animals were kept in a picket rotation system, and the pasture consisted of Brachiaria brizantha and Cynodon plectostachyus (in the summer), Avena sativa (during winter), and mineral salt and water at ad libitum. The use of animals was approved by the Committee of Ethics in the Use of Animals (CEUA) of the Pontifical Catholic University of Paraná, and registered under number 01047/2016.

How the ovulation synchronization was performed is shown in Figure 1. Seven days before the start of the study (d-7), the animals were weighed $(\mathrm{kg})$ and their body condition score was defined. On day zero of the study (d0), an intravaginal progesterone (P4) single-use implant was inserted and $2 \mathrm{mg}$ of estradiol benzoate (EB, IM) was administered. On d7, the 
animals received $500 \mathrm{mcg}$ (IM) of prostaglandin $\mathrm{F}_{2 \alpha}\left(\mathrm{PGF}_{2 \alpha}\right)$. On $\mathrm{d} 8$, the $\mathrm{P} 4$ implant was removed and $400 \mathrm{IU}$ of equine chorionic gonadotropin
(eCG, IM) and $1 \mathrm{mg}$ estradiol cypionate (EC, IM) were injected. On $\mathrm{d} 10$, the fixed-time artificial insemination (FTAI) was performed.

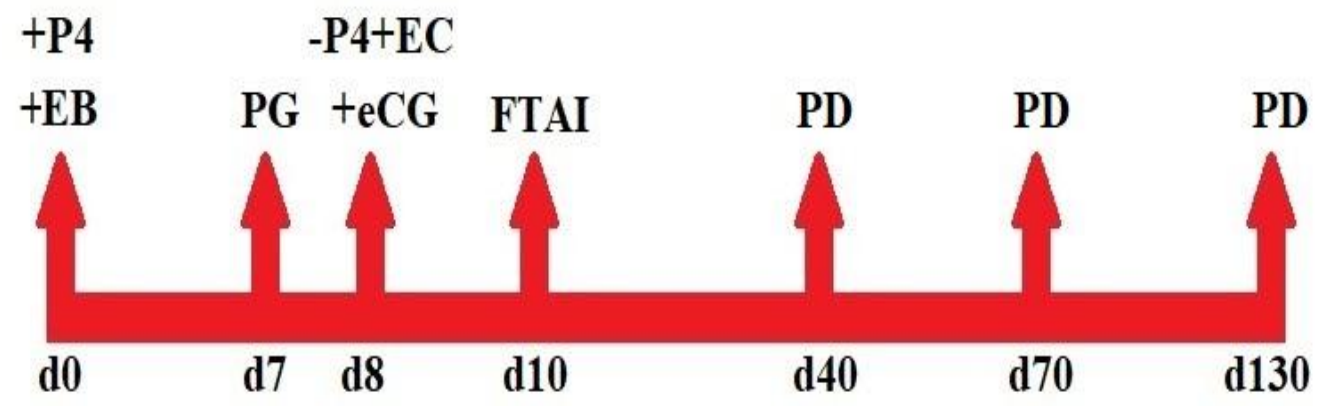

Figure 1. Diagram of the ovulation synchronization protocol performed in bovine females for FTAI and subsequent pregnancy diagnoses.

Caption: P4 - Progesterone implant (Primer Monodose, Agener União Saúde Animal, Brazil); EB Estradiol Benzoate (Gonadiol, Zoetis, Brazil); PG - Prostaglandin (Lutalyse, Zoetis, Brazil); EC Estradiol Cypionate (E.C.P., Pfyzer, Brazil); eCG - Equine Chorionic Gonadotrophin (Novormon, Zoetis, Brazil); FTAI - Fixed-Time Artificial Insemination; PD - Pregnancy Diagnosis via transrectal ultrasonography.

Pregnancy diagnoses (PD) were performed with ultrasonography on $\mathrm{d} 40, \mathrm{~d} 70$, and $\mathrm{d} 130$ (corresponding to 30, 60, and 120 days, respectively after FTAI). AI was performed with frozen sperm obtained from Aberdeen Angus bulls at an Artificial Insemination Station. During the AI, the semen batches were randomly removed from the liquid nitrogen canister and the animals were inseminated in the order in which they entered the containment trunk. The identification number of each batch was noted. After the FTAI, two samples from each batch were collected for motility analysis. In total, ten batches of three different bulls were used. Ultrasonography and AI were both performed by the same technician.

A sample of each batch used in the AI was analyzed at the laboratory with four different TTs: one RTT $\left(30 \mathrm{~min} / 46^{\circ} \mathrm{C}\right)$ and three STT; STT1 $\left(60 \mathrm{~min} / 38^{\circ} \mathrm{C}\right)$, STT2 $\left(180 \mathrm{~min} / 38^{\circ} \mathrm{C}\right)$, and STT3 $\left(300 \mathrm{~min} / 38^{\circ} \mathrm{C}\right)$. RTT and STT3 were used because they are the standard tests (Dimitropoulos, 1967). STT1 and STT2 were used as intermediate STT3 incubation times, chosen as alternative combinations $\left(60 \mathrm{~min} / 38^{\circ} \mathrm{C}\right.$ and $180 \mathrm{~min} / 38^{\circ} \mathrm{C}$ ) because they were not described in the available literature, although some authors (Arruda et al., 1992; Siqueira et al., 2007; Emerick et al., 2011; Sellem et al., 2015) have worked with times and temperatures different from those of standard TTs.

To control the temperature of the tests, the samples were distributed into test tubes with support grids and placed in a water bath. After the stipulated time intervals, an aliquot of each sample was withdrawn for evaluation. All materials that came into contact with the semen (blades, cover slips, and pipette tips) were heated to $37^{\circ} \mathrm{C}$ as recommended (Manual..., 1998). Following the time and temperature control proposed for the study, an aliquot of $10 \mu \mathrm{L}$ semen was placed on a slide and covered with a cover slip and observed with an optical microscope (Bioptika, model B20, Brazil). Sperm motility was assessed by analyzing sperm videos recorded with a smartphone camera (Samsung Galaxy S5) coupled to the optical microscope; (the camera was coupled to the optical microscope with a smartphone universal adapter) using the CASA plugin by ImageJ software, available on the internet (Wilson-Leedy and Ingermann, 2007).

Short duration videos (4 seconds on average) were recorded, from two different fields of each sample for the computerized analysis of sperm motility. The setting used to record the videos was 59 frames/second. Because the computerized software accepts only files in the AVI format, the 
videos were converted to AVI format and analyzed using the plugin settings indicated in the article by Giaretta et al. (2017) and the configuration settings indicated in the articles by Hoflack et al. (2007), Sellem et al., (2015) and Polo (2016). For each video, 30 frames were analyzed (131-160 frames), according to the method described by Bertol et al. (2014) and Sellem et al. (2015). To read the videos without interference, it was necessary to make some adjustments in the program (ImageJ). Therefore, the background was removed to prevent any soiling or scratching of the slides from appearing. The threshold contrast of the images was adjusted, so that the spermatozoa remained prominent.

Statistical analysis was performed using the StatGraphics software (StatPoint Technologies Inc., 2009, The Plains, USA). Levene's test was used to evaluate the homogeneity of variance, a fundamental premise for the subsequent analyses of variance (ANOVA), followed by the Tukey's test. The analyses of variance included the effects of the TT, batch, and interaction between test and batch. The correlation between sperm motility measured with TT and fertility was verified with the Pearson's correlation test. To compare the pregnancy rate between each of the batches, the Fisher's exact test was used. Statistical significance was set at $\mathrm{P}<0.05$.

\section{RESULTS AND DISCUSSION}

Sperm motility is one of the most important parameters to be evaluated (Rodríguez-Martínez, 2003), not only before freezing but also after semen thawing because of its association with the capacity of a sperm to fertilize an egg (Vincent et al., 2012). Sperm motility is indispensable if cells are to reach the fertilization site (Siqueira et al., 2007). Furthermore, it is an indication of sperm viability and integrity after cryopreservation and storage at low temperatures (Nagy et al., 2015). The sperm motility data of the semen batches subjected to the four TT as well as the PR at 30, 60, and 120 days after the FTAI are shown in Table 1.

Table 1. Bovine sperm motility data after each of the four different thermoresistance tests performed in each batch used in the study, number of inseminated cows with each batch, and pregnancy rates found in each of the pregnancy diagnoses performed after FTAI

\begin{tabular}{|c|c|c|c|c|c|c|c|c|c|}
\hline \multirow[t]{2}{*}{ Bull } & \multirow[t]{2}{*}{ Batch } & \multicolumn{4}{|c|}{$\begin{array}{l}\text { Motility } \\
(\%)\end{array}$} & $\begin{array}{l}\text { Inseminated } \\
\text { Animals (n) }\end{array}$ & \multicolumn{3}{|c|}{$\begin{array}{l}\text { Pregnancy Rate } \\
\text { (days) }(\%)\end{array}$} \\
\hline & & RTT & STT1 & STT2 & STT3 & & 30 & 60 & 120 \\
\hline \multirow{4}{*}{ A } & 1 & 19.45 & 22.45 & 22.00 & 5.05 & 46 & $69.56^{\mathrm{a}}$ & $65.22^{\mathrm{a}}$ & $60.87^{\mathrm{a}}$ \\
\hline & 2 & 34.00 & 34.05 & 25.00 & 13.50 & 61 & $57.38^{\mathrm{ab}}$ & $52.46^{\mathrm{ab}}$ & $52.46^{\mathrm{ab}}$ \\
\hline & 3 & 18.00 & 24.10 & 22.30 & 8.00 & 11 & $63.64^{\mathrm{ab}}$ & $54.54^{\mathrm{ab}}$ & $54.54^{\mathrm{ab}}$ \\
\hline & 4 & 10.06 & 34.50 & 16.30 & 9.75 & 18 & $61.11^{\mathrm{ab}}$ & $55.55^{\mathrm{ab}}$ & $55.55^{\mathrm{ab}}$ \\
\hline \multirow{4}{*}{ B } & 5 & 22.80 & 51.80 & 24.40 & 14.40 & 21 & $42.86^{\mathrm{b}}$ & $38.09^{\mathrm{b}}$ & $38.09^{b}$ \\
\hline & 6 & 16.80 & 21.50 & 15.80 & 6.30 & 15 & $60.00^{\mathrm{ab}}$ & $53.33^{\mathrm{ab}}$ & $53.33^{\mathrm{ab}}$ \\
\hline & 7 & 20.0 & 20.00 & 16.00 & 11.50 & 7 & $42.86^{\mathrm{ab}}$ & $42.86^{\mathrm{ab}}$ & $42.86^{\mathrm{ab}}$ \\
\hline & 8 & 15.60 & 24.30 & 16.80 & 5.70 & 8 & $75.00^{\mathrm{ab}}$ & $75.00^{\mathrm{ab}}$ & $75.00^{\mathrm{ab}}$ \\
\hline \multirow{3}{*}{ C } & 9 & 21.60 & 35.80 & 7.22 & 6.90 & 12 & $83.33^{\mathrm{a}}$ & $83.33^{\mathrm{a}}$ & $75.00^{\mathrm{a}}$ \\
\hline & 10 & 20.10 & 17.00 & 10.40 & 5.35 & 16 & $68.75^{\mathrm{ab}}$ & $68.75^{\mathrm{ab}}$ & $62.50^{\mathrm{ab}}$ \\
\hline & Total & & & & & 215 & 61.86 & 57.67 & 55.81 \\
\hline
\end{tabular}

* Different letters in the same column indicate statistical difference according to Pearson's correlation test. Caption: RTT - Rapid Thermoresistance Test $\left(30 \mathrm{~min} / 46^{\circ} \mathrm{C}\right)$; STT1 - Slow Thermoresistance Test 1 $\left(60 \mathrm{~min} / 38^{\circ} \mathrm{C}\right)$; STT2 - Slow Thermoresistance Test 2 (180min $\left./ 38^{\circ} \mathrm{C}\right)$; STT3 - Slow Thermoresistance Test $3\left(300 \mathrm{~min} / 38^{\circ} \mathrm{C}\right)$.

Semen batches used in the insemination of each cow were selected at random; therefore, the number of animals inseminated with each semen batch presented a disparity. However, this variation in sample intensity (number of samples) was not a problem in the execution and interpretation of the statistical analysis of the data; this is because the analysis took into consideration the number of repetitions in each treatment, which in this case are the batches used. Homoscedasticity is an important factor to consider when homogeneity is not present in sample intensity. Thus, to perform the main parametric statistical tests (ANOVA and Tukey), 
the variances between the groups (batches) should be homogeneous among each other, a fact verified in all cases in this study with Levine's test $(\mathrm{P}=0.05)$.

For TTs carried out at the same temperature but different incubation times (STT1, STT2 and STT3), an inverse relationship was observed between the permanency time in the water bath and sperm motility (Table 1). Once a sperm cell recovers its metabolic function after thawing, it begins to consume the nutrients in the conservation medium, resulting in the production of metabolites. As this process continues, the amount of nutrients available to the cells is reduced, consequently decreasing the energy production needed for the movement of the spermatozoon tail. The gametes deteriorate with increasing storage duration mainly by oxidative stress and the production of endogenous free radicals, which impair their viability (Maia, 2014). This accounted for the decrease in percentage motility over time after thawing. The temperature for analysis also influences sperm motility (Matos et al., 2008). According to Verstegen et al. (2002), the temperature indicated for the analysis of animal semen is $38^{\circ} \mathrm{C}$, which is very close to the normal body temperature. High temperatures and/or long periods of incubation during TT negatively affects bovine sperm motility (Vianna et al., 2009).

Data from this study demonstrated that the mean motility value in each test was different (Tukey's test). Following the analysis, TTs were homogeneously divided into three groups, according to their mean values. The lowest motility rates were found in the first group (STT3). In the second group (RTT and STT2), the means did not differ statistically from each other and, the highest motility rates were found in the last group (STT1) (Table 2).

Table 2. Values of $r$ and $\mathrm{P}$ relating to the correlation between each of the four Thermoresistance Tests (TT) used in the semen batches analyzed in the study and the Pregnancy Rates after Fixed-Time Artificial Insemination in Bos taurus x Bos taurus indicus females in each of the pregnancy diagnoses performed

\begin{tabular}{cccccccc}
\hline \multirow{2}{*}{ TT } & $\begin{array}{c}\text { Mean } \\
\text { Motility } \\
(\mathrm{x} \pm \mathrm{s} ;(\%)\end{array}$ & \multicolumn{7}{c}{$\begin{array}{c}\text { Pregnancy Rate } \\
\text { (days) }\end{array}$} \\
\cline { 3 - 9 } & & \multicolumn{7}{c}{30} & \multicolumn{7}{c}{60} \\
& & $r$ & $\mathrm{P}$ & $r$ & $\mathrm{P}$ & $r$ & $\mathrm{P}$ \\
\hline RTT & $19.84 \pm 6.13^{\mathrm{b}}$ & -0.186 & 0.606 & -0.158 & 0.663 & -0.208 & 0.565 \\
STT1 & $28.55 \pm 10.48^{\mathrm{c}}$ & -0.272 & 0.447 & -0.291 & 0.415 & -0.308 & 0.386 \\
STT2 & $17.62 \pm 5.87^{\mathrm{b}}$ & -0.543 & 0.105 & -0.644 & 0.044 & -0.579 & 0.080 \\
STT3 & $8.63 \pm 3.46^{\mathrm{a}}$ & -0.774 & 0.009 & -0.752 & 0.012 & -0.748 & 0.013 \\
\hline
\end{tabular}

*Different letters in the same column indicate statistical difference according to Tukey's test. Values of $\mathrm{P}<0.05$ indicate statistical difference. Caption: RTT - Rapid Thermoresistance Test $\left(30 \mathrm{~min} / 46^{\circ} \mathrm{C}\right)$; STT1 - Slow Thermoresistance Test $1\left(60 \mathrm{~min} / 38^{\circ} \mathrm{C}\right)$; STT2 - Slow Thermoresistance Test $2\left(180 \mathrm{~min} / 38^{\circ} \mathrm{C}\right)$; STT3 - Slow Thermoresistance Test $3\left(300 \mathrm{~min} / 38^{\circ} \mathrm{C}\right)$.

Using Pearson's correlation test, negative correlations were found between sperm motility measured with some of the TTs and PR after FTAI. Sperm motility measured with STT2 negatively correlated with $\mathrm{PR}$ at 60 days after FTAI $(\mathrm{r}=-0.644, \mathrm{P}=0.044)$, whereas sperm motility measured STT3 (1967 standard test) negatively correlated with PR at 30,60 , and 120 days after FTAI $(r=-0.774,-0.752$, and -0.748 ; $\mathrm{P}=0.009,0.012$, and 0.013 , respectively) (Table 2 ). These results invalidate the hypothesis of this study since it was not possible to establish any positive correlation between sperm motility measured with TTs and PR after FTAI.
These findings differ from those of Dimitropoulos (1967), Amann (1989) and Farrell et al. (1998), who reported a positive correlation between sperm motility and fertility in a given semen sample. However, the negative correlations observed here corroborate the findings of Emerick et al. (2011), who reported a correlation of -0.22 between sperm motility and fertility rate soon after thawing. Furthermore, the negative correlations observed corroborate the findings of Vianna et al. (2009), who a reported a PR between $65 \%$ and $75 \%$ in semen samples that showed $0 \%$ sperm motility in TT. Emerik et al. (2011) justified that spermatozoa may have 
high motility and still be infertile because of structural and acrosomal abnormalities.

In order for the oocyte to be fertilized, only one spermatozoon, one motile cell capable of surpassing the uterine environment, is needed. When aliquots of samples are analyzed, they may not be representative of the behavior of all the cells that make up the population since the sperm population is naturally heterogeneous (Rodríguez-Martinez, 2003). Standerholen et al. (2015) reported conflicting results between studies involving motility and fertility because of the large number of spermatozoa present in the sample. This may mask the results since only a small portion of the sample can be observed with the microscope (Siqueira et al., 2007; Standerholen et al., 2015). This may account for the negative correlation between sperm motility and fertility observed in this study.

The change in the energy available to cells may also justify the better performance of semen samples with low sperm motility in TT. Since there is less competition between cells for the available nutrients in the medium (there are fewer cells moving, using the available nutrients, and producing metabolites), the few motile cells can stay mobile much longer and with more vigor. This is different from a sample with pronounced motility, where millions of sperm compete for nutrients, and thus, remain motile for a shorter time and with less vigor.

Intrinsic factors of the female genital tract (anatomy, uterine contractions, sperm displacement, spermicidal factors, immune reactions, etc. (Hawk, 1987)) may also influence the AI result. Thus, it is clear that an in vitro situation does not perfectly mimic the conditions and behavior of the sperm cell in vivo. The findings of this study, along with those already described in the literature (Arruda et al., 1992; Vianna et al., 2009; Brito, 2016), support the evidence that motility found in TT does not influence the fertility of the sperm. Currently, semen straws that could be used in FTAI to generate good results are being discarded because they have motility below the $15 \%$ minimum level established for commercialization (Manual..., 1998); this study should alert all that such a practice should be discontinued since motility in TT does not necessarily influence sperm fertility.
For the motility measurements, the use of the CASA plugin allowed objective analysis (motility) to be performed. Analyses were performed according to the procedure described at the method section (Hoflack et al., 2007; Wilson-Leedy and Ingermann, 2007; Giaretta et al., 2017). Sperm motility videos were captured using a smartphone camera coupled to a common optical microscope, making the motility analysis objective, cost effective, and reliable. The different PR verified in each of the batches can be expressed as the difference in the quality of the ejaculates, including morphological spermatic defects. Ten semen batches from three different bulls were analyzed. Variations in PR results were observed, including that of different semen batches of the same animal (Table 1).

The different batches of semen came from different ejaculates, thus generating diverse characteristics. The quality of the semen varied since the process of production and maturation of spermatozoa takes about 60 days (Romano and Brinsko, 2014). Thus, any exposure to stressors (such as temperature fluctuations, problems associated with hormonal origin, or drugs) can alter the quality of the sperm cell produced (Freneau, 2011). According to Chenoweth (2005), the frequency and intensity of these defects depend on the time and intensity of exposure to stressors. These reports allow to conclude that the variations in the PR of each batch were closely associated with the morphological differences between the cells that make up the ejaculate.

According to Borges et al. (2008), the mean PR in Brazilian cows subjected to FTAI was between $25 \%$ and $70 \%$. Therefore, the $55.81 \%$ obtained in this study at the end of the 120 days and after one synchronization, is satisfactory (Table 1). Cows had gestational losses of $4.78 \%$ between 30 and 60 days after FTAI and $1.91 \%$ between 60 and 120 days after FTAI, corroborating reports (Mello, 2014) that losses are more frequent in the first 35 days of gestation. This study reinforces the fact that the losses are more pronounced between 30 and 60 days after FTAI. Santos et al. (2004), Beal et al. (1992), and Stevenson et al. (2003) reported losses between $6.5 \%$ and $10.8 \%$ in the first interval between PD. Previous studies have reported a loss of $11.42 \%$ after FTAI (Santos et al., 2004), which is much higher than that 
observed in this study. Gestational losses in this study are lower than those reported in the literature. This may be due to the type of management given to the animals during the days of the application of the FTAI protocol. The animals were driven and managed using the animal welfare precepts. Hygiene at the time of AI can also be considered as an influential factor in reducing gestational losses. In addition, good BCS and the weight of the animals can be classified as variables associated with good reproductive performance observed in this study, as gestation losses can be influenced by immunity, nutrition, lactation, and thermal stressors (Mello, 2014).

Emerick et al. (2011) concluded that routine tests are not always sufficient and efficient to determine the fertility of a sample since the analyses are population-based, and not all cells that make up the sample have the same attributes. Amann (1989) highlighted the need for a laboratory test to determine the fertility of a sample rather than the evaluation of a set of characteristics. Therefore, the search for laboratory tests with greater effectiveness and direct association with fertility in the field must continue and be intensified.

\section{CONCLUSIONS}

It was concluded that the thermoresistance tests, performed after semen thawing, do not provide consistent parameters to determine the quality of the bovine semen and the pregnancy rates resulting from its use in the field after administration of a FTAI protocol. Semen thermoresistance tests, as performed and currently used, do not translate the fertility potential of a bovine semen sample onto the field. The minimum percentage motility established for the classification of semen to be of "good quality" should be reviewed. This study has shown the need for other studies and the development of new techniques for in vitro semen analysis to establish a valid correlation between sperm motility and field fertility.

\section{REFERENCES}

AMANN, R.P. Can the fertility potential of a seminal sample be predicted accurately?. J. Androl., v.10, p.89- 98, 1989.
ARRUDA, R.P.; BARNABE, V.H.; ALENCAR, M.M.; BARNABE, R.C. Avaliação de sêmen congelado de bovinos. Provas lenta e rápida de termoresistência: efeitos sobre a fertilidade. Braz. J. Res. Anim. Sci., v.1, p.131-137, 1992.

BEAL, W.E.; PERRY, R.C.; CORAH, L.R. The use of ultrasound in monitoring reproductive physiology of beef cattle. J. Anim. Sci., v.70, p.924-929, 1992.

BERTOL, M.A.F.; WEISS, R.R.; FUJITA, A.S. et al. Dois diluentes comerciais na criopreservação de espermatozoides de epidídimo de touros. Ciênc. Rural, v.44, p.1658-1663, 2014.

BORGES, L.F.K.; FERREIRA, R.; SIQUEIRA, L.C. Sistema para inseminação artificial sem observação de estro em vacas de corte amamentando. Ciênc. Rural, v.39, p.496-501, 2008.

BRITO, L.F.C. A multilaboratory study on the variability of bovine semen analysis. Theriogenology, v.85, p.254-266, 2016.

CHENOWETH, P. Genetics sperm defects. Theriogenology, v.64, p.457-468, 2005.

DIMITROPOULOS, E. La significaction du test de la thermoresistence dans l'appreciation de la valeur fécondante du sperme congele. Ann. Med. Vet., v.4, p.215-224, 1967.

EMERICK, L.L.; DIAS, J.C.; VALE FILHO, V.R. et al. Avaliação da integridade de membrana em espermatozoide bovino criopreservado para prever o índice de prenhez. Ciênc. Anim. Bras., v.12, p.536546, 2011.

FARRELL, P.B.; PRESICCE, D.A.; BROCKETT, C.C.; FOOTE, R.H. Quantification of bull sperm characteristics measured by computer assisted semen analysis (CASA) and the relationship to fertility. Theriogenology, v.49, p.871-879, 1998.

FRENEAU, G.E. Aspectos da morfologia espermática em touros. Rev. Bras. Reprod. Anim., v.35, p.160-170, 2011.

GIARETTA, E.; MUNERATO, M.; YESTE, M. et al. Implementing an open-access CASA software for the assessment of stallion sperm motility: relationship with other sperm quality parameters. Anim. Reprod. Sci., v.176, p.11-19, 2017.

GRAHAM, J.K.; MOCÉ, E. Fertility evaluation of frozen/thawed semen. Theriogenology, v.64, p.492504, 2005.

HAWK, H.W. Transport and fate of spermatozoa after insemination of cattle. J. Dairy Sci., v.70, p.1487$1503,1987$. 
HOFLACK, G.; OPSOMER, G.; RIJSSELAERE, T. et al. Comparison of computer-assisted sperm motility analysis parameters in semen from Belgian Blue and Holstein-Friesian bulls. Reprod. Domest. Anim., v.42, p.153-161, 2007.

HOUGHTON, P.L.; LEMENAGER, R.P.; MOSS, GE. Prediction of postpartum beef cows body composition using weight to height ratio and visual body condition score. J. Anim. Sci., v.68, p.1428-1437, 1990.

MAIA, M.S. Tecnologia de sêmen e inseminação artificial em caprinos. Acta. Vet. Bras., v.8, p.389-395, 2014.

MANUAL para exame andrológico e avaliação de sêmen animal. Belo Horizonte: CBRA, 1998. 49p.

MATOS, D.L.; ARAÚJO, A.A.; ROBERTO, I.G.; TONIOLLI, R. Análise computadorizada de espermatozoides: revisão de literatura. Rev. Bras. Reprod. Anim., v.32, p.225-232, 2008.

MELLO, R.R.C. Perdas reprodutivas em fêmeas bovinas. Agropecu. Cient. Semi Árido, v.10, p.7-23, 2014.

NAGY, A.; POLICHRONOPOULOS, T.; GÁSPÁRDY, A. et al. Correlation between bull fertility and sperm velocity parameters generated by computer-assisted semen analysis. Acta Vet. Hung., v.63, p.370-381, 2015.

POLO, G. Análise computadorizada (CASA) de sêmen equino: uso do ImageJ com câmera de celular e microscópio óptico. 2016. 58f. Dissertação (Mestrado em Ciência Animal) - Escola de Ciências da Vida, Pontifícia Universidade Católica do Paraná, Curitiba, PR.

RODRÍGUEZ-MARTÍNEZ，H. Laboratory semen assessment and prediction of fertility: still utopia? Reprod. Domest. Anim., v.38, p.312-318, 2003.

ROMANO, J.E.; BRINSKO, S.P. Fisiologia reprodutiva do macho. In: KLEIN, B.G. (Ed.). Cunningham tratado de fisiologia veterinária. Rio de Janeiro: Elsevier, 2014. p.451-459.

SÁ FILHO, M.F.; MARQUES, M.O.; BARUSELLI, P.S. Indução de ciclicidade e IATF em novilhas zebuínas. Biotecnologia da reprodução em bovinos. In: SIMPÓSIO INTERNACIONAL DE REPRODUÇÃO ANIMAL, 4., 2010, Londrina. Anais... Londrina: [s.n], 2010. p.79-100.
SANTOS, J.E.; THATCHER, W.W.; CHEBEL, R.C. et al. The effect of embryonic death rates in cattle on the efficacy of estrus synchronization programs. Anim. Reprod. Sci., v.81-82, p.513-535, 2004.

SELLEM, E.; BROEKHUIJSE, M.L.W.J.; CHEVRIER, L. et al. Use of combinations of in vitro quality assessments to predict fertility of bovine semen. Theriogenology, v.84, p.1447-1454, 2015.

SIQUEIRA, J.B.; GUIMARÃES, J.D.; COSTA, E.P. et al. Relação da taxa de gestação com sêmen bovino congelado e testes de avaliação espermática in vitro. Rev. Bras. Zootec., v.36, p.387-395, 2007.

STANDERHOLEN， F.B.; WATERHOUSE， K.E.; LARSGARD, A.G. et al. Use of immobilized cryopreserved bovine semen in a blind artificial insemination trial. Theriogenology, v.84, p.413-420, 2015.

STEVENSON, J.S.; JOHNSON, S.K.; MEDINABRITOS, M.A. et al. Resynchronization of estrus in cattle of unknown pregnancy status using estrogen, progesterone, or both. J. Anim. Sci., v.81, p.16811692, 2003.

VERSTEGEN, J.; IGUER-OUADA, M.; ONCLIN, K. Computer assisted semen analyzers in andrology research and veterinary practice. Theriogenology, v.57, p.149-179, 2002.

VIANNA, F.P.; PAPA, F.O; ZAHN, F.S. et al. Thermoresistance sperm tests are not predictive of potential fertility for cryopreserved bull semen. Anim. Reprod. Sci., v.113, p.279-282, 2009.

VINCENT, P.; UNDERWOOD, S.L.; DOLBEC, C. et al. Bovine semen quality control in artificial insemination centers. Anim. Reprod., v.9, p.153-165, 2012.

WILSON-LEEDY, J.G.; INGERMANN, R.L. Development of a novel CASA system based on open source software for characterization of zebrafish sperm motility parameters. Theriogenology, v.67, p.661-672, 2007.

ZHANG, B.R.; LARSSON, B.; LUNDEHEIM, N. et al. Prediction of bull fertility by combined in vitro assessments of frozen-thawed semen from young dairy bulls entering an AI-programme. Int. J. Androl., v.22, p.253-260, 1999. 